\title{
Biology and Impacts of Pacific Island Invasive Species. 2. Boiga irregularis, the Brown Tree Snake (Reptilia: Colubridae) ${ }^{1}$
}

\author{
Gordon H. Rodda and Fulie A. Savidge ${ }^{3}$
}

\begin{abstract}
The Brown Tree Snake, Boiga irregularis (Merrem, 1802), was accidentally transported to the island of Guam shortly after World War II. Over the following two decades it spread throughout the island with little public or professional recognition of its extent or impacts. This secretive nocturnal arboreal snake occurs in all habitats on Guam, from grasslands to forests. Under the right conditions, it is capable of high rates of reproduction and population growth. The Brown Tree Snake caused the extirpation of 13 of Guam's 22 native breeding birds and contributed to the extirpation of several species of native bats and lizards. Guam's 12 forest birds were especially impacted, with 10 species eliminated and the other two severely reduced. In addition, the snake continues to substantially impact domestic poultry, pets, the island's electrical power infrastructure, and human health. To protect other vulnerable Pacific islands, the U.S. government annually spends several million dollars inspecting cargo outbound from Guam to exclude Brown Tree Snakes. Cargo destinations most at risk are in Micronesia, especially the Northern Mariana Islands, but Guam also has direct air transportation links to Hawai'i that will soon be supplemented with direct ship traffic. Ultimately, all Pacific islands are at risk but especially those obtaining cargo through Guam.
\end{abstract}

The Brown Tree Snake, Boiga irregularis (Merrem, 1802), is not an especially unusual snake, though it is longer (up to $3 \mathrm{~m}$ total length), skinnier, more nocturnal, and more arboreal than an average snake. Its notoriety derives from the profound ecological impacts it had on vertebrate life upon its postwar arrival on the island of Guam. In this paper we review the history of the snake's impacts on Guam and outline management efforts to

${ }^{1}$ This research was funded primarily by the Office of Insular Affairs, U.S. Department of the Interior, with support from the U.S. Geological Survey and U.S. Fish and Wildlife Service. This review provides an update on a previous comprehensive review (Rodda et al. 1999b). Manuscript accepted 31 August 2006.

${ }^{2}$ U.S. Geological Survey Fort Collins Science Center, 2150 Centre Avenue, Building C, Fort Collins, Colorado 80526 (e-mail: gordon_rodda@usgs.gov).

${ }^{3}$ Department of Fish, Wildlife, and Conservation Biology, Colorado State University, Fort Collins, Colorado 80523-1474.

Pacific Science (2007), vol. 61, no. 3:307-324

(C) 2007 by University of Hawai'i Press

All rights reserved prevent new invasions by this species on other Pacific islands and, if possible, to reverse the ecological and economic dislocations witnessed on Guam.

\section{NAME}

Boiga irregularis is most often called the Brown Tree Snake, though a variety of names are in local use (Rodda et al. 1999b). Our favorite is northern Australia's "Doll's Eye," which recognizes the disproportionately large eyes of this species, especially when it is young (Kinghorn 1964).

The Brown Tree Snake is one of about 1,800 species of modern snakes lumped into the poorly resolved and presumably polyphyletic family of "typical" snakes: Colubridae. A cluster of similar genera is sometimes characterized as the subfamily Colubrinae (formerly placed in Boiginae). The genus Boiga is an Asian radiation of slender rear-fanged snakes, with 33 described species (EMBL [European Molecular Biology Laboratory] Web site accessed 31 January 2006: http://www.emblheidelberg.de/ uetz/LivingReptiles.html); in- 


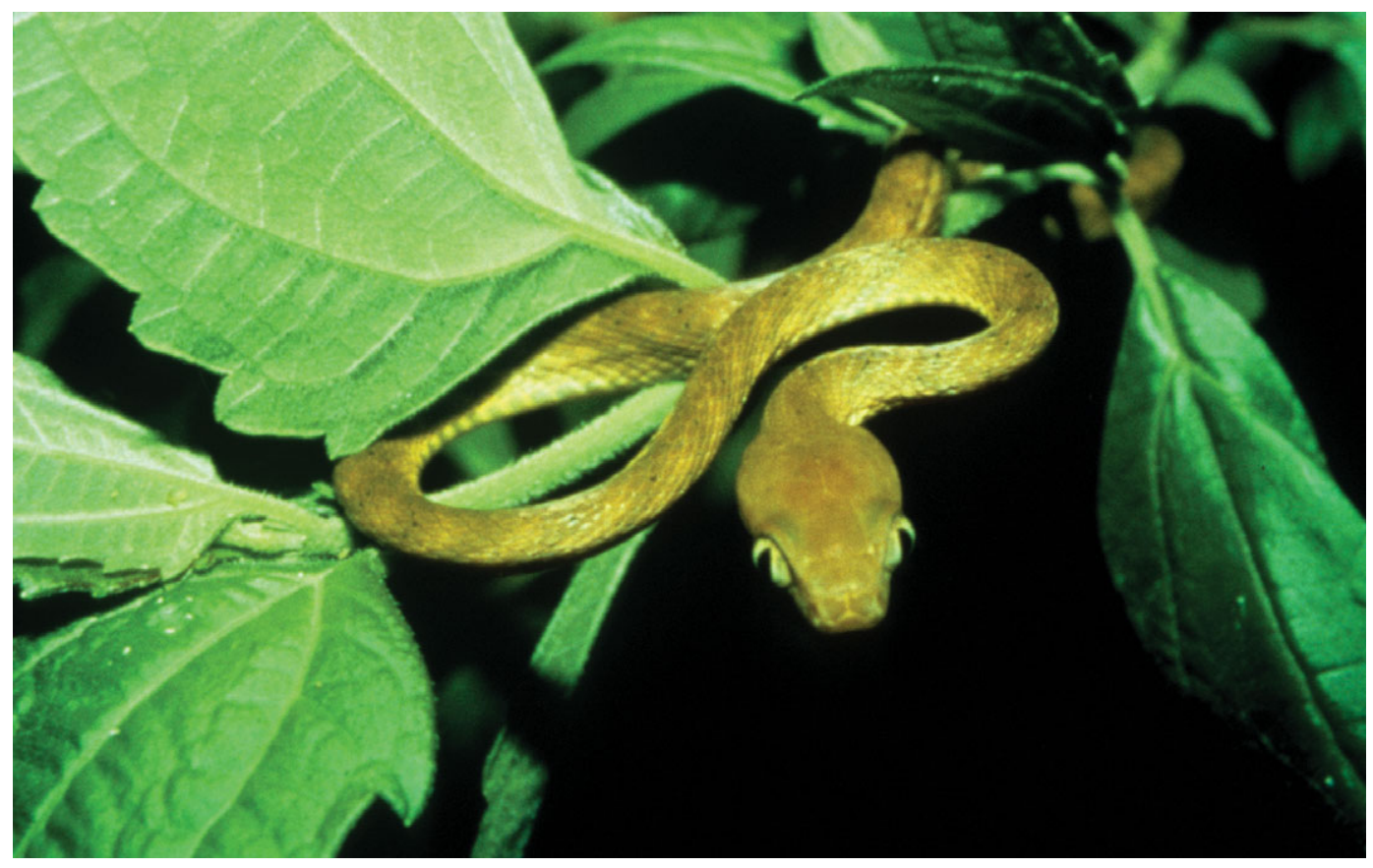

Figure 1. A juvenile Brown Tree Snake from Guam, showing the Guam population's characteristic shade (light/ medium brown) and vague black banding, as well as the species' characteristic defensive pose, short snout, and large eyes. (Photo by G. Rodda)

sofar as it is known, all members of the genus are nocturnal and all but one are arboreal. The easternmost representative of this Asian radiation is the Brown Tree Snake. As currently recognized, Boiga irregularis includes all of the closely related brown Boiga found east and south from Sulawesi to Australia and the Solomon Islands (see a later section on Geographic Distribution), though various proposals have been suggested to recognize locally distinctive forms. The species name irregularis recognizes the diversity of morphology in the species.

DESCRIPTION AND ACCOUNT OF VARIATION

\section{Species Description}

The Brown Tree Snake conveys the impression of having a large head in relation to the diameter of its neck and body. For a snake of this length, the head size is actually normal, but the body is extraordinarily slender
(Rodda et al. 1999b). Any hole that will admit a Brown Tree Snake's head will allow passage of the entire snake (unless a very large meal has recently been ingested). The snout is short and the eyes are large, with the elliptical pupil characteristic of nocturnal species (Figure 1). The teeth are of moderate length, the upper rearmost of which are enlarged and grooved to facilitate penetration of venom into prey (Vest et al. 1991, Hayes et al. 1992, 1993, Jackson and Fritts 1995, Mackessy et al. 2006). The venom is relatively mild for humans (Weinstein et al. 1991, 1993), though it overlaps with the toxicity of that of species considered dangerous (e.g., North American Copperheads, Agkistrodon contortrix). Compared with the copperhead, however, the Brown Tree Snake lacks a means for injecting the venom (only capillary action conveys the venom into prey). Toxicity varies greatly among prey species, with select birds and lizards being highly susceptible to neurotoxic elements of the venom (Mackessy et al. 2006). 
Brown Tree Snakes have tails that average $21 \%$ of their total length. This proportion is intermediate among snakes and relatively short compared with most arboreal snakes (Guyer and Donnelly 1990). No sexual size dimorphism in relative tail length or width has been reported, though male Brown Tree Snakes often achieve a larger total length than do female Brown Tree Snakes (Savidge 1991, Rodda et al. 1999b). The degree of sexual size dimorphism is sensitive to the sampling method. The largest recorded male on Guam was $3.1 \mathrm{~m}$ in total length, whereas the largest recorded female was only $1.9 \mathrm{~m}$. These lengths are exceptional, however; the 99th percentile sizes on Guam are $2.1 \mathrm{~m}$ $(n=4,870)$ and $1.5 \mathrm{~m}(n=5,223)$ for males and females, respectively. These sizes are larger than those reported for most of the native range, especially Australia, where maximum total lengths are typically reported to be $1.8 \mathrm{~m}$ (males). On Guam, the smallest hatchlings that have been found are about $330 \mathrm{~mm}$ snout-vent length (SVL), whereas Australian hatchlings are reported to be smaller (250-275 mm SVL [Gow 1976, Shine 1991, Greer 1997]).

In coloration and scutellation, Boiga irregularis rangewide lives up to its "irregular" description, while having relatively invariant coloration and scutellation at any one locality (Figure 2). Typically the species has vague to distinct narrow to wide blackish banding dorsally on a medium brown background, countershaded to a cream to yellowish venter flecked with tiny lighter and darker marks. However, in parts of Australia the banding may be whitish, blue, or red. Details of scu-

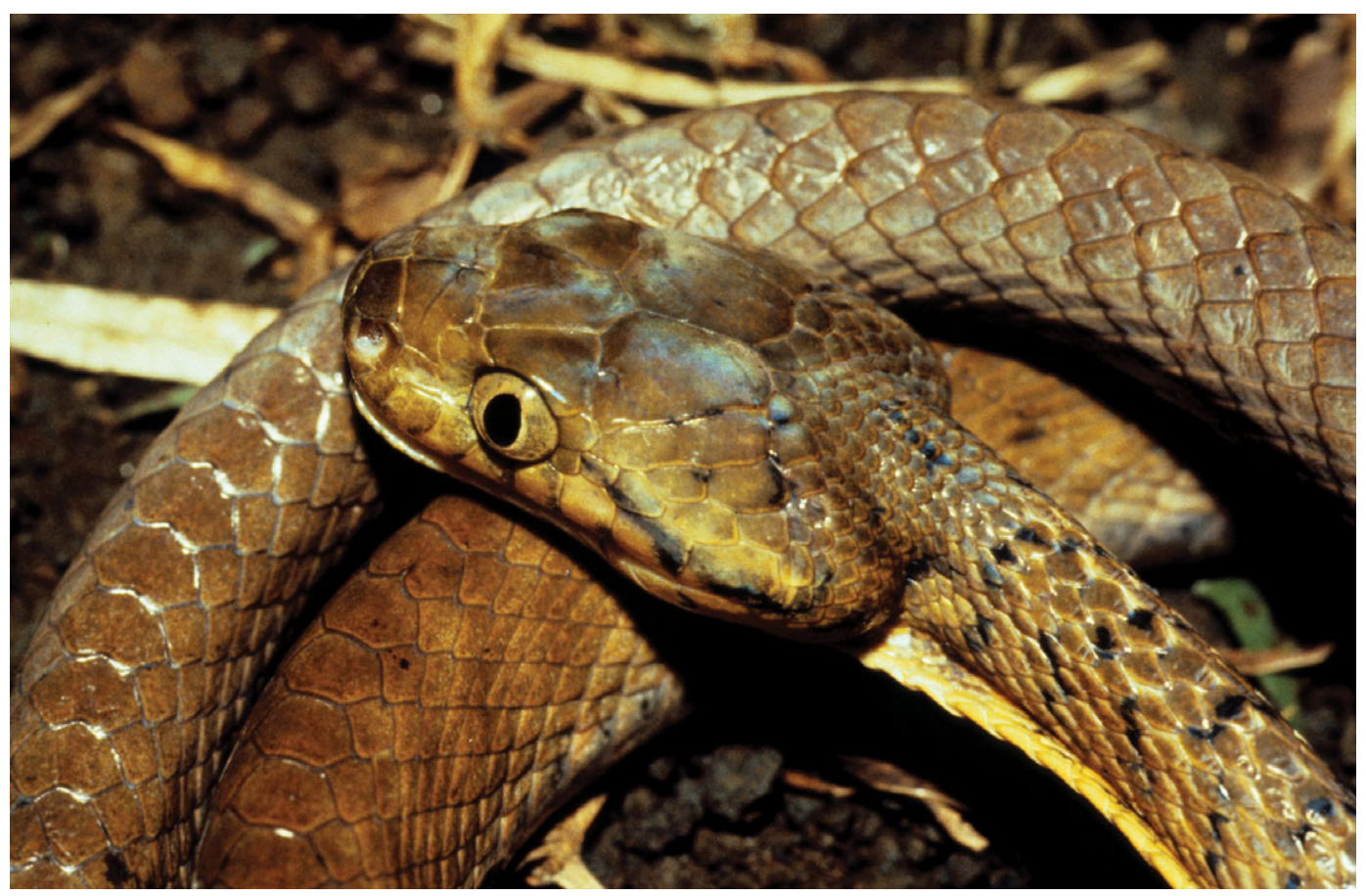

Figure 2. An adult Brown Tree Snake from Karkar Island, Papua New Guinea, showing the species' large head, the relatively smaller eyes characteristic of adults, characteristically darker shade of this population compared with that on Guam (redder), more definite black marks on head and neck (compared with Guam population), and transversely enlarged middorsal scale row (found irregularly throughout the species). (Photo by G. Rodda) Color versions of Figures 1 and 2 are available through the PDF version of this article, available at muse.jhu.edu, www.bioone.com, or by contacting the authors. Additional photos may be found at http://www.fort.usgs.gov/resources/education/bts/ bts_home.asp or at http://www.invasivespeciesinfo.gov/animals/bts.shtml. 
tellation are provided in Rodda et al. (1999b) and Whittier et al. (2000).

\section{Distinguishing Features}

A combination of traits rather than any single diagnostic character should be considered:

(1) Size: SVL 250-2,700 mm

(2) Color pattern: banded or unmarked; brown, blue, or reddish brown background color

(3) Head shape: blunt short snout with wide quadrates (relative to neck) and large eyes

(4) Body shape: very slender, with mass about $100 \mathrm{~g}$ for a $1,000-\mathrm{mm}$ SVL individual

(5) Head scalation: typical of colubrids

(6) Body scalation: often but not always with transversely enlarged middorsal scales

(7) Dorsal scale rows in midbody region: $17-25$

(8) Anal scale: undivided or divided

(9) Number of ventrals: 217-286

(10) Number of subcaudals: $65-130$

\section{Intraspecific Variation}

As already noted, the coloration and scutellation of the Brown Tree Snake is variable from place to place. Only in Australia have systematists attempted to split the species or recognize subspecies, treating forms in the northwest of Australia as subspecies of the full species fusca (Kinghorn 1964, Storr et al. 1986, Ehmann 1992, Whittier et al. 2000). The distinguishing characteristics are inconsistent from observer to observer, however, and different geographic boundaries of division have been proposed (Rodda et al. 1999b). Furthermore, the defining morphological characters have not been mirrored in molecular evidence of gene flow restriction, suggesting a lack of genetic structuring in Australia (S. Donnellan and others, pers. comm.). Most island isolates of Brown Tree Snakes do show genetic structure, but no distinctive forms have been formally recognized.
ECONOMIC IMPORTANCE AND

ENVIRONMENTAL IMPACT

\section{Detrimental}

Economic impacts from the Brown Tree Snake on Guam include damage to electrical power infrastructure, loss of pet and domestic animals, human envenomations, higher costs of shipping from Guam, and threats to the tourism industry.

The most quantified economic factor has been electrical system costs (Fritts et al. 1987, Fritts 1994, 2002, Fritts and Chiszar 1999, Burnett et al. 2004). Burnett et al. (2004) extrapolated from the electrical system damage experienced on Guam to the expense associated with a similar level of outages throughout the state of Hawai $i$, estimating a staggering \$1.7 billion in annual costs. Based on the recovery of electrocuted snakes at the site of electrical "faults," Guam experiences a snake-caused power outage about every other day on average, but many of the outages affect only a small area. Costs include direct damage to the electrical infrastructure (damaged transformers, generators, etc.), emergency restoration costs, loss of revenue to the power company while power is not being delivered, lost customer productivity while power-dependent systems (e.g., computer networks) are down, disruption of normal urban functions (e.g., elevator outages, traffic jams associated with nonfunctioning traffic signals), and the costs associated with mitigation (requirement for extra generators, etc.). No analysis has considered all of these costs simultaneously, and many are dependent on poorly documented assumptions about how electrical power systems would work in the absence of Brown Tree Snakes. Nonetheless, it is clear that the economic costs of frequent power outages are a substantial burden on business and residential customers.

Brown Tree Snakes consume many pet animals on Guam, but this impact has not been quantified. Anecdotally, the loss is primarily to neonatal mammals, especially puppies, and cage birds. The primary loss of domestic animals is of poultry (Savidge 1987a, Fritts and McCoid 1991). Loss of local suppliers of eggs requires costly importation by air. It is 
difficult to assign exact costs, because this requires making assumptions about the state of Guam's poultry industry in the absence of snakes.

The primary victims of envenomations are infants sleeping at home in their cribs (Fritts et al. 1990, 1994). A similar pattern of infant envenomations is recorded for Asian residents of areas inhabited by the elapid snakes of the genus Bungarus (Fritts and McCoid 1999). Adult humans appear not to be very vulnerable to Brown Tree Snake venom, because they remove the biting snake before capillary action introduces substantial venom. Although no human fatalities have been recorded for bites by Boiga, at least 10 Guam infants have been placed on ventilators or otherwise put on life support while being treated. The economic cost of such treatment is presumably minor compared with the psychological trauma associated with possible loss of a child.

These economic burdens increase the cost of attracting desired employees and conducting business on Guam. Inspections of cargo leaving Guam undoubtedly boost the cost of shipping, but most of the cost is now borne by the mainland taxpayer. Guam shippers voluntarily arrange and wait for inspections by U.S. Department of Agriculture Wildlife Services, but this burden is certainly buried in shipping fees. Various plans have been suggested to assess shippers a fee for the inspection costs now carried by the federal taxpayer, and these would further increase the expense of shipping from Guam.

The military community experiences many of the same burdens from the Brown Tree Snake as do civilians (power outages, envenomations, loss of pets, difficulties recruiting employees from off island, etc.), and it also pays Wildlife Services for the costs ( $\$ 1-2$ million/yr) of inspecting materials shipped from Guam. The U.S. Department of Defense is the source of the majority of cargo leaving Guam (Daniel Vice, pers. comm.).

Guam's economy is primarily dependent on tourism from Asia (Guam Department of Commerce 1998). Although few Guam tourists personally encounter Brown Tree Snakes, ophiophobia is based more on fears and impression than coldly calculated risks.
No quantification has been published for lost tourist revenues. Tourists can easily change their destination from Guam to snake-free sites such as Saipan or Hawai'i that still host a variety of birds. Preliminary cost estimates for tourism impacts should the Brown Tree Snake reach Hawaili are in the range $\$ 0.5-$ 1.5 billion annually (S. Shwiff, pers. comm.).

Direct ecological costs of the introduction of the Brown Tree Snake to Guam have been relatively well documented, but indirect losses (e.g., loss of forest trees due to absence of essential seed dispersers) have been largely overlooked. The direct losses include extirpation of most birds (Savidge 1987b, Rodda et al. 1997, Fritts and Rodda 1998), population reduction of the flying fox (Wiles 1987, 1989), and extirpation or reduction of several lizard species (Rodda and Fritts 1992a). The cumulative effect of these losses is quite striking; there are areas on Guam that lack all native vertebrates except for a few species of small lizards. Thus, processes that involve vertebrates, such as insectivory, frugivory, seed dispersal, pollination, and processes dependent on these phenomena, have undoubtedly been disrupted, the consequences of which have not yet been explored. However, quantification of these disruptions is complex, in part due to introductions of other species, such as ungulates and various invertebrates, and the impacts of numerous typhoons on vegetative structure. Typhoons are natural, but climate change may have elevated the frequency of typhoons in recent decades (U.S. Fish and Wildlife Service 2005).

\section{Beneficial}

Introduced small mammals (including rats) are less numerous than they were before the arrival of the Brown Tree Snake (Savidge 1987b).

\section{Regulatory Aspects}

To date, Brown Tree Snake regulation has been mostly voluntary, with only a requirement for a permit needed from the U.S. Fish and Wildlife Service for importation for scientific or exhibition purposes. Importation 
for pet ownership is not permitted in the United States. However, the primary risk of spread is not through intentional transport but through accidental movement. No regulatory requirements exist regarding cargo sanitization or inspections, though cargo inspection certification has been much discussed among Guam and its trading partners. The U.S. Congress requested a study of possible cargo inspection certification (7 USC 8504) through the Brown Tree Snake Control and Eradication Act of 2004 (P.L. 108384), but participation in any such program is currently voluntary.

\section{GEOGRAPHIC DISTRIBUTION}

The distribution of the Brown Tree Snake includes its native range of coastal Australia, Papua New Guinea and a large number of islands in northwestern Melanesia (Fritts 1988), and the introduced population on Guam (Table 1). The Brown Tree Snake is found on almost every island from Sulawesi to Guadalcanal, and south across the Torres Strait to the northern and eastern coasts of Australia (see Rodda et al. $1999 b$ for a range map). It is found on a few outlier islands as well (e.g., Santa Cruz Islands in the Solomons), where it may have been prehistorically introduced by humans. However, the only unequivocally established introduced population is on Guam. Persistent reports from the island of Saipan (Fritts et al. 1999) suggest that the snake may be in the process of becoming established there, but clear evidence of establishment or recruitment is lacking. Sightings on Saipan in the last 5 yr have clustered just west of the airport, though earlier specimens were collected at several sites away from the port or airport (N. Hawley, pers. comm.). All but one of eight specimens from Hawai'i predate the 1994 initiation of Wildlife Service's control program on Guam (Fritts et al. 1999), and the Hawai'i sightings have not been clustered in time or space. An old record for Java (Capocaccia 1977) needs corroboration; if documented this would be a second extralimital population. Published records or museum specimens are known for the islands listed in Table 2.
НАВITAT

\section{Climatic Requirements and Limitations}

The habitat requirements or habitat-selection criteria of this species have not been studied, although the snake's population biology and movements have been quantified in several habitats. Its distribution suggests difficulty in surviving in sites exposed to hard frosts; the southern limit of Brown Tree Snakes lies in the suburbs of Sydney, Australia, at the northern limit of hard frosts. In New Guinea the upper-elevation limit is the altitudinal frost line (Greer 1997). Brown Tree Snakes hibernate in the higher latitudes of their range (Covacevich and Limpus 1973, Hoser 1980), which suggests that it is not direct exposure to low temperatures that is limiting. Low prey availability or other factors (vulnerability to predation when cool) represent potential benefits of inactivity during winter.

Brown Tree Snakes do not occur in the arid interior of Australia, even where the prevailing temperatures are within the range tolerated by the snake in more coastal areas. The reason for this limitation is not understood. Relative unavailability of prey, a shortage of trees, or simple desiccation may be responsible. There is some evidence for each of these. To the best of our knowledge, data to contrast prey availability between coastal and interior Australia are unavailable. Morton and James (1988) quantified lizard prey availability in the arid interior $(2.9 \mathrm{~kg} / \mathrm{ha})$, which is an order of magnitude lower than lizard prey availability in the Marianas (mean $=30.0 \mathrm{~kg} / \mathrm{ha}$, range $7-65 \mathrm{~kg} / \mathrm{ha}$ [unpubl. data]), but comparable figures are not available for coastal areas of Australia. Brown Tree Snakes are associated with trees, which are scarce in central Australia. The species utilizes savanna habitat on Guam, where desiccation is presumably reduced due to shading in the tall, dense grass. Furthermore, Guam's grasslands are interdigitated with strings of trees. Anderson (2002) and Anderson et al. (2003) found that Brown Tree Snakes from Guam are relatively vulnerable to desiccation. However, no Brown Tree Snakes from arid areas (such as Australia) have been tested. Thus many factors could impinge on the abil- 
TABLE 1

Distribution of Brown Tree Snakes in the Pacific

\begin{tabular}{|c|c|c|c|c|}
\hline Location & $\begin{array}{l}\overrightarrow{\tilde{U}} \\
\text { D. } \\
\text { D. }\end{array}$ & $\begin{array}{l}\overrightarrow{\tilde{U}} \\
\text { हू } \\
\text { \& }\end{array}$ & 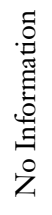 & Comments \\
\hline American Samoa & & $\mathrm{X}$ & & \\
\hline Australia & $\mathrm{X}$ & & & $\begin{array}{l}\text { Native, abundant in more mesic sites along } \mathrm{N} \\
\text { and } \mathrm{E} \text { coasts }\end{array}$ \\
\hline Bonin Islands & & $\mathrm{X}$ & & \\
\hline Cocos Islands & & $\mathrm{X}$ & & \\
\hline Cook Islands & & $\mathrm{X}$ & & \\
\hline Easter Island & & $\mathrm{X}$ & & \\
\hline Fiji & & $\mathrm{X}$ & & \\
\hline French Polynesia & & $\mathrm{X}$ & & \\
\hline Galápagos Islands & & $\mathrm{X}$ & & \\
\hline Guam & $\mathrm{X}$ & & & Introduced, superabundant but subject to control \\
\hline Hawaiian Islands & & $\mathrm{X}$ & & Not native nor believed to be established \\
\hline Indonesia & $\mathrm{X}$ & & & Common from Sulawesi to Papua New Guinea \\
\hline Japan & & $\mathrm{X}$ & & \\
\hline Juan Fernández & & $\mathrm{X}$ & & \\
\hline Kiribati & & $\mathrm{X}$ & & \\
\hline Marshall Islands & & $\mathrm{X}$ & & \\
\hline Micronesia & & $\mathrm{X}$ & & \\
\hline Nauru & & $\mathrm{X}$ & & \\
\hline New Caledonia & & $\mathrm{X}$ & & \\
\hline New Zealand & & $\mathrm{X}$ & & \\
\hline Niue & & $\mathrm{X}$ & & \\
\hline Norfolk Island & & $\mathrm{X}$ & & \\
\hline Northern Mariana Islands & $\mathrm{X}$ ? & & & Possible incipient population on Saipan \\
\hline Palau & & $\mathrm{X}$ & & \\
\hline Papua New Guinea & $\mathrm{X}$ & & & Native, abundant (below 1,850 m) \\
\hline Philippines & & $\mathrm{X}$ & & \\
\hline Pitcairn Island & & $\mathrm{X}$ & & \\
\hline Solomon Islands & $\mathrm{X}$ & & & Native, abundant on most islands \\
\hline Taiwan & & $\mathrm{X}$ & & \\
\hline Tokelau Island & & $\mathrm{X}$ & & \\
\hline Tonga & & $\mathrm{X}$ & & \\
\hline Tuvalu & & $\mathrm{X}$ & & \\
\hline Vanuatu & & $\mathrm{X}$ & & \\
\hline Wake Island & & $\mathrm{X}$ & & \\
\hline Wallis and Futuna & & $\mathrm{X}$ & & \\
\hline
\end{tabular}

ity of the Brown Tree Snake to survive in or spread to more arid localities.

\section{Habitat and Resource Requirements and Limitations}

On Guam, where climate, predation, and prey are not limiting, Brown Tree Snakes occupy all habitats (native forest, introduced forest, agroforest, shrubland, rocklands, grassland, suburban, and urban). Habitat, independent of prey availability, does not seem to be a key factor in their distribution. However, we do not fully understand their requirements through all phases of their life cycle, especially breeding; they may need to move among key microenvironments (Fritts and Rodda 1998). Juvenile Brown Tree Snakes 
TABLE 2

Individual Islands (Exclusive of Australia and New Guinea) Inhabited by Brown Tree Snakes

\begin{tabular}{lc}
\hline \hline Mariana Islands & Guam \\
Solomon Islands & Bougainville, Buka, Choiseul, Gizo, Guadalcanal, Isabel, Malaita, Mono, \\
& New Georgia, Ngela Is., Ranongga, Santa Cruz Is., Simbo, Vangunu, \\
& Vella Lavella \\
Islands north of Papua & Feni Is., "Jasper" (Schoutens), Karkar, Los Negros, Lou, Manam, Manus, \\
New Guinea (PNG) & Maron, New Britain, New Ireland, Sable, Seleo, Umboi \\
Islands east of PNG & Fergusson, Kiriwina, Muyua, Goodenough, Normanby, Misima, Sudest, \\
& Samarai, Yule \\
Islands south of PNG (incl. & Badu, Bathurst, Cotton, Daru, Dauan, Dunk, Groote Eylandt, Hammond, \\
Australian islands) & Horn, Inglis, Lindeman, Long, Maer, Marchinbar, Melville, Prince of \\
Islands west of West Irian & Wales, Saibai, Thursday, Yule, Wigram \\
& Ambon, Aru Is., Auki, Bacan, Biak, Boano, Buru, Buton, Gorong, \\
& Halmahera, Kai Is., Manipa, Mansinam, "Mefoor," Misool, Morotai, \\
& Obi, Salawati, Sangihe Is., Sanana, Seram, Sulawesi, Ternate, Yapen, \\
\hline
\end{tabular}
"Is."

Note: Islands listed alphabetically within each archipelago. Uncertain localities set off by quotation marks. Island groups denoted by

eat exclusively lizards (Savidge 1988, Greene 1989, Shine 1991), and lizards are more available in some habitats than others, but these differ from place to place. Similarly, adult Brown Tree Snakes on Guam are now heavily dependent on introduced rodents, which often have different habitat requirements than lizards.

Predation is not an important limiting factor for Guam populations of the Brown Tree Snake. Although feral domestic predators (cats, dogs, and pigs) take Brown Tree Snakes opportunistically, almost all recorded snake mortality is associated with starvation and low individual body weight (G.H.R., K. Dean-Bradley, T. H. Fritts, and J.A.S., unpubl. data). Average body condition of snakes throughout Guam declined irreversibly in all habitats coincident with the peak of the Brown Tree Snake irruption (early 1980s), though snakes in grassland habitats exhibit consistently better body condition than those in other habitats. What predation there is from feral animals on Guam is not obviously correlated with any particular habitat.

Prey availability is important to the success of Brown Tree Snakes. An analysis of Brown Tree Snake densities in relation to various local attributes indicated that all of the explained variation (83\%) was attributed to availability of different types of prey (Rodda et al. 1999 c). Many small islands of the world, including the major islands in the Marianas, show exceptionally high prey densities (Rodda and Dean-Bradley 2002); if this trend holds uniformly, we expect that Brown Tree Snakes could thrive on most tropical or subtropical islands.

\section{Ecosystem and Community Types Invaded}

To date (2007) Brown Tree Snakes have been documented to colonize only one locality: Guam (though Java is an undocumented second possibility). Because the snake spread rapidly throughout the available land area on Guam, and no failed colonizations are known, we have no data on any limitations associated with ecosystem or community types although population densities vary with habitat type.

\section{HISTORY}

Brown Tree Snakes arrived on Guam around 1949 , most likely as a passive stowaway on World War II war materiel being salvaged from the New Guinea area through the large port facility at Manus Island (Savidge 1987b, Rodda et al. 1992). Through interviews and historical documents, Savidge (1987b) docu- 
mented the spread across Guam. The first snakes were noticed near the Fena Reservoir/ Santa Rita area of Guam. They spread concentrically from that location, reaching the farthest point of the island (Ritidian Point, ca. $37 \mathrm{~km}$ from the point of initial colonization). The date of arrival in the north is not well documented; one record was obtained in 1968, but the next records were from 1982 (Savidge 1987b). Presumably populations were at low densities before general detection by the public. Brown Tree Snakes are usually arboreal, nocturnal, and cryptic; thus their presence could be easily overlooked.

Extrapolating from capture rates achieved during the 1980s (Rodda et al. 1992), and recognizing that small snakes were not caught by the traps then (or now) in use (Boyarski 2005, Rodda et al. 2007), the peak density of Brown Tree Snakes in favorable habitats was probably in excess of $100 /$ ha. Such a density is unprecedented for a nonaggregated large snake (Rodda et al. 1999c), which average around 2/ha (range 0.1-14 [Parker and Plummer 1987]).

Snakes throughout Guam grew abruptly skinnier in the early 1980s, suggesting that they had exceeded their carrying capacity nearly simultaneously islandwide (G.H.R., K. Dean-Bradley, T. H. Fritts, and J.A.S., unpubl. data). Coincident with this decline in body condition was the extirpation of most native prey species (Savidge 1987a, 1991). What permitted the snake to thrive on Guam following the loss of most native prey species? Continued survival was possible because the snake's abundance was supported by abundant introduced prey species, especially a skink (Carlia ailanpalai), geckos (especially Gehyra sp.), rodents (Rattus spp. and Mus musculus), a shrew (Suncus murinus), and a variety of introduced birds (Columba livia, Streptopelia bitorquata, and Passer montanus) (Rodda et al. 1997, Fritts and Rodda 1998). By the mid 1990s, the snake's populations on Guam appeared to have reached a dynamic equilibrium, at roughly half the estimated peak density in the 1980s (Rodda et al. 1992 and unpubl. data). No directional change in density has been observed since that time.
PHYSIOLOGY

Ecophysiology of snakes tends to focus on thermoregulation, with subsidiary interests in water balance, metabolism, and sensory systems, especially sensory systems crucial for food acquisition. In all respects the physiology of the Brown Tree Snake is nonremarkable, though not necessarily representative of a typical snake. For example, the Brown Tree Snake is a thermal conformer. Anderson and colleagues studied thermoregulation in the Brown Tree Snake by radiotelemetry in the wild and in thermal gradients. A wide variety of temperatures was experienced in both situations (Anderson 2002, Anderson et al. 2005). Brown Tree Snake skin has relatively high permeability to water, suggesting a vulnerability to desiccation. To the extent it is known, Brown Tree Snake metabolism appears unremarkable.

As suggested by the conspicuous eyes of the Brown Tree Snake, this species is perhaps more dependent on eyesight than many snakes. The balance between dependence on chemical and visual cues has been the subject of a long series of experiments by Chiszar and colleagues (Chiszar et al. 1985, 1988a, $b$, 1999, Chiszar and Kandler 1986, Chiszar 1990, 1992, 1999; see also Gee 2002). The most novel finding is that Brown Tree Snakes will cease pursuit of a prey item that can be seen to be absent, whereas some, perhaps many, other snakes will continue pursuit if chemical cues remain (Weldon et al. 1994, Schwenk 1995). Studies of relative importance of various cues have been impeded by chronic discrepancies between the behavior of Brown Tree Snakes in captivity and in the wild (Chiszar et al. 1997). Despite the propensity of wild Brown Tree Snakes to thrive in close proximity to human habitation, Brown Tree Snakes appear to be unusually stressed by captivity (Mathies et al. 2001, Aldridge and Arackal 2005, Moore et al. 2005).

\section{REPRODUCTION}

Probably no aspect of Brown Tree Snake biology has been more frustrating to scientists than reproduction. Although this species 
is obviously a successful reproducer, it has proven extremely difficult to breed under controlled conditions. The most likely explanation is that the species' reproduction is exceptionally vulnerable to human disturbance (Mathies et al. 2001, Aldridge and Arackal 2005, Moore et al. 2005). A few attempts at captive propagation have been partially successful (Barnett 1993, Greene and Mason 2000, Mathies and Miller 2003). More often courtship has been observed without it necessarily progressing to viable eggs (Greene and Mason 1998, Greene 1999, Mathies et al. 2004). These and other studies support the impression that chemical cues play a central role in courtship (Greene et al. 2001, 2002, Mason and Greene 2001, Greene and Mason 2003 , 2005), though success at isolating the responsible chemicals has not been reported (Murata et al. 1991), with the negative evidence implying that a bouquet of chemicals rather than a single compound is involved.

The most novel finding to emerge from this body of work is that Brown Tree Snakes can be induced to breed by cooling to temperatures not found on Guam (Greene 1999, Greene and Mason 2000, Mathies and Miller 2003, Mathies et al. 2004). This is consistent with Hoser's (1999) report of winter breeding at the extreme southern limit of the species' range.

Breeding on Guam takes place year-round (McCoid 1994, Savidge et al. 2007), with some evidence for peak hatching in the wet season (Rodda et al. 1999b); thus peak copulation and oviposition probably occur in the preceding dry season. However, some recruitment occurs in every month of the year on Guam, at least in some years (Savidge et al. 2007). Guam's climate is moderately seasonal, with least rain in March $(78 \mathrm{~mm})$ and most in October $(411 \mathrm{~mm})$; annual temperature variation is only $1.4^{\circ} \mathrm{C}$ (Savidge et al. 2007). Year-round reproduction is an impediment to contraceptive control of the Brown Tree Snake, because any temporary inhibitors would need to be administered continuously. In the more temperate or seasonal parts of the snake's range, reproduction is seasonal (Shine 1991, Whittier and Limpus 1996, Bull et al. 1997).
One enduring mystery of Brown Tree Snake reproduction is the location of eggs. Though single clutches of eggs have been found opportunistically (Savidge 1986, Ehmann 1992, 1993), too few have been found to make definitive statements about their location. The two clutches reported by Ehmann (1993) were found in deep underground crevices and were attended by the females for 18 and 27 days, respectively. Presumably researchers' inability to locate Brown Tree Snake eggs is due to the females' secretive behavior and concealed oviposition sites.

The frequency of reproduction is presumed to be annual in Australia but is unknown for Guam or tropical localities with nonseasonal reproduction. The rate of appearance of hatchlings during a half-year sample in a 5-ha fenced population on Guam implies that recruitment (to the hatchling stage) is only about 0.5 female offspring per female per year (G.H.R., K. Dean-Bradley, T. H. Fritts, and J.A.S., unpubl. data). Although those data are too preliminary to deduce a typical breeding frequency on Guam, breeding does not appear to be frequent. Too few clutches have been found to characterize typical clutches, but gravid females have contained 3-8, occasionally to 12 eggs (Zwinenberg 1978, Greene 1989, Shine 1991).

Though hard facts about Brown Tree Snake reproduction are scarce, it does not appear that this species has a particularly high reproductive output. Like humans, it probably achieves its high population density through high survivorship rather than exceptional fecundity.

\section{POPULATION DYNAMICS}

We can estimate a potential rate of spread or population expansion for Brown Tree Snakes that can be used cautiously to anticipate control needs for other localities at risk. As indicated in the section on History, the initial spread of Brown Tree Snakes on Guam covered $37 \mathrm{~km}$ (the distance from the point of original infestation to Ritidian Point) in potentially less than $20 \mathrm{yr}$. We do not know that there was more than one locus of infestation, as might occur if human transport facili- 
tated the spread of the snake across Guam, but neither can that possibility be entirely ruled out (either on Guam or for prospective infestations). Using $19 \mathrm{yr}$ as a possible minimum, the estimated linear rate of spread would be $1.95 \mathrm{~km} / \mathrm{yr}$ or about $2 \mathrm{~km} / \mathrm{yr}$. Peak density was not achieved at Ritidian Point until shortly after 1982 . If that scenario were to hold for a larger island (e.g., $\mathrm{O}^{\prime} \mathrm{ahu}$ ), it might take many decades for a Brown Tree Snake irruption to peak, whereas for a smaller island (e.g., Rota, just north of Guam), the peak irruption might be achieved much sooner.

We can roughly estimate the population growth of the Brown Tree Snake population on Guam with reference to two landmarks: first colonization and the estimated population in the early 1980s. Based on finding no variability in mitochondrial DNA, L. H. Rawlings (1995 and pers. comm.) declared that all Brown Tree Snakes then on Guam descended from a single female colonist. That female was probably on Guam around 1949. There were an estimated 2 million Brown Tree Snakes on Guam in the early 1980s (population estimation methods given in Fritts and Rodda 1998). To increase a population one million-fold (from 2 to 2 million) requires about 20 doublings; spaced evenly over about $35 \mathrm{yr}$, this implies a doubling time of about $1.75 \mathrm{yr}$, or an annual population increase of about $40 \%(r=0.396)$. This value reflects a population expanding at an extraordinarily high rate (and the population must have maintained this average rate of increase for more than $30 \mathrm{yr}$ ). It may be unrealistic to assume that such a high rate would prevail in new colonizations, both because conditions elsewhere may not be as optimal as in the Marianas (Rodda et al. 1999c) and because countermeasures will undoubtedly be taken to suppress new Brown Tree Snake colonizations.

\section{RESPONSE TO MANAGEMENT}

Brown Tree Snake control has been practiced primarily to prevent dispersal of snakes from Guam to other islands (interdiction). A secondary effort has been directed at restoring wildlife populations on Guam through landscape-level control of snake populations (wildlife restoration).

The primary effort (interdiction) has been focused on ports and airports (Rodda et al. 1998); it has been very successful in those areas (Vice and Pitzler 2002). The primary tools for interdiction control currently in use include visual searches, dog-aided searches, and snake traps (Rodda and Fritts 1992b, Engeman and Linnell 1998, Engeman et al. 1998, Rodda et al. 1998, Campbell et al. 1999, Vice and Engeman 2000, Vice and Vice 2004, Vice et al. 2005). Prey base reduction and snake barriers have a secondary role in current interdiction management (references just cited, Perry et al. 1998). One employee can maintain about 175 traps or one search dog. Search dog teams (one handler plus one dog) interdict $60-90 \%$ of snakes planted in cargo that a team inspects (Engeman et al. 2002; J. Gibbons, M. A. Hall, D. S. Vice, and C. S. Clark, pers. comm.). Permanent removal of Brown Tree Snakes is believed to require barriers to prevent snake recolonization (Savarie et al. 2001); unfortunately, barriers that can withstand the severe hurricanes to which Guam is routinely subjected are expensive $(\$ 400+/ \mathrm{m})$, and implementation has been correspondingly limited.

Several toxicants are effective against Brown Tree Snakes (Savarie and Bruggers 1999), and acetaminophen is registered for this use both in aerial broadcast and bait stations (Savarie et al. 2001, Johnston et al. 2002, National Wildlife Research Center 2003). Bait station use is indicated for interdiction purposes or for wildlife restoration where vulnerable nontarget species are present and ground-based access to bait stations is practical. Aerial broadcast offers the prospect of landscape-level control, even in areas without easy access. Costs have not yet been published for aerial broadcast of acetaminophen, but bait station use appears roughly comparable in cost with that of snake traps (Daniel Vice, pers. comm.). Complete cost benefit analyses of available control tools have not yet been published. No Brown Tree Snake eradications have been completed on any scale, but may be possible, at least on a modest scale (Rodda et al. 1999a, 2002). 


\section{NATURAL ENEMIES}

One management tool that has not been developed for Brown Tree Snakes is natural enemies. The traditional form of control would be to obtain a natural predator from the snake's native range. There are no known predators that specialize in consuming Brown Tree Snakes (Rodda et al. 1999c). There are two snakes that are known to consume Brown Tree Snakes opportunistically: Ophiophagus bannab and Stegonotus cucullatus. The former is commonly known as the King Cobra and would not be an appropriate control tool (for obvious reasons), whereas the latter is a harmless egg-eating snake. It coexists with the Brown Tree Snake in areas where the Brown Tree Snake is common, suggesting that whatever depressive effect it has is relatively modest.

Another approach would be to introduce a poisonous prey item for the Brown Tree Snake. An obvious candidate would be the poisonous toad Bufo marinus. This exotic prey already occurs on Guam without any apparent impact on the snake.

Several authors have explored the possibility of using a disease or parasite found in the snake's native range (Whittier and O'Donoghue 1998, Telford 1999, Caudell 2001, Caudell et al. 2002, Jakes et al. 2003), with the uniform conclusion that all known natural diseases and parasites are not known to have demographic significance (or even clinical significance) as a biocontrol agent.

Finally, some have suggested that novel disease agents (those not found in the wild and therefore for which the Brown Tree Snake might not have evolved resistance) might be of some value (Dobson 1988, Holzman 1999). A blue-ribbon panel of pest management experts recently explored this option (Colvin et al. 2005) and concluded that the risks of this approach and the expense inherent in safe development were beyond the reach of available funds and should not be pursued at this time.

PROGNOSIS

The existing U.S.D.A. Wildlife Services program to interdict Brown Tree Snakes leaving
Guam has been highly successful (Colvin et al. 2005). This has greatly reduced the risks to Guam's trading partners. Concern surrounds rapidly escalating military activities on Guam (and concomitant increases in cargo movements from Guam), the traditional difficulty in sustaining successful governmental programs over the long run (as complacency develops and new priorities emerge), and the difficulty in detecting and eradicating new colonizations of Brown Tree Snakes when they do occur. The islands of greatest risk are those that receive the greatest amount of cargo through Guam and those that lack native snakes (prey that have coevolved with snakes are less likely to be vulnerable: Rodda et al. 1999b); these include Micronesia generally, but especially the Northern Mariana Islands, and Hawai'i. Palau may be less at risk than are other parts of Micronesia, because Palau has native snakes that consume birds. The other localities in the Caroline Islands are at great risk, because they receive much cargo through Guam and do not have welldeveloped wildlife management infrastructures to inspect cargo or detect incipient colonizations of Brown Tree Snakes. The Northern Mariana Islands have an excellent Brown Tree Snake interdiction program, which is especially desirable because they get virtually all of their cargo through Guam. Hawai'i gets only a small percentage of its cargo through Guam, but that percentage will increase as direct surface shipping from Guam to Hawai'i begins in 2006. In addition, the total amount of cargo passing through Hawai' $i$ is large, so that even though the percentage coming through Guam ports is small, the risks are substantial and continuous. One special consideration with Hawai' $i$ is that it serves as a transportation hub for the entire Pacific region; thus an infestation of Hawai' $i$ could have severe regional consequences.

At the current time the risk of Brown Tree Snake introductions to the Pacific from the snake's native range is considered to be relatively minor, for two reasons: (1) the density of Brown Tree Snakes is generally much lower in the snake's native range than it is in Guam, and (2) little cargo destined for tropical and subtropical areas originates in 
the snake's native range (e.g., Port Moresby, Honiara, Darwin, Halmahera). That could change as Indonesia industrializes or food shipments increase from Australia's tropical regions. Fortunately, a good model interdiction program currently in place in Guam may provide a useful template for Brown Tree Snakes in their native range, or for other invasive species of similar biology.

\section{Literature Cited}

Aldridge, R. D., and A. Arackal. 2005. Reproductive biology and stress of captivity in male Brown Treesnakes (Boiga irregularis) on Guam. Aust. J. Zool. 53:249-256.

Anderson, N. L. 2002. Thermal preferences, metabolic rate, and water flux of the Brown Treesnake (Boiga irregularis) in the laboratory and on Guam. Ph.D. diss., Ohio State University, Columbus.

Anderson, N. L., T. E. Hetherington, B. H. Coupe, G. Perry, J. B. Williams, and J. Lehman. 2005. Thermoregulation in a nocturnal, tropical, arboreal snake. J. Herpetol. 39:82-90.

Anderson, N. L., T. E. Hetherington, and J. B. Williams. 2003. Validation of the doubly labeled water method under low and high humidity to estimate metabolic rate and water flux in a tropical snake (Boiga irregularis). J. Appl. Physiol. 95: 184-191.

Barnett, B. 1993. Breeding the banded Brown Tree Snake, the Nth. Terr 'Night Tiger' (Boiga irregularis). Vic. Herpetol. Soc. "Monitor" 5 (1): 11-14.

Boyarski, V. L. 2005. Trappability and activity of juvenile Brown Treesnakes (Boiga irregularis) on Guam. M.S. thesis, Colorado State University, Fort Collins.

Bull, K. H., R. T. Mason, and J. M. Whittier. 1997. Seasonal testicular development and sperm storage in tropical and subtropical populations of the Brown Tree Snake (Boiga irregularis). Aust. J. Zool. 45:479488.

Burnett, K., B. A. Kaiser, and J. A. Roumasset. 2004. Optimal public control of exotic species: Preventing the Brown Tree Snake (Boiga irregularis) from invading Hawaii.
Abstract and poster. Hawai'i Conservation Conference, Honolulu.

Campbell, E. W., III, G. H. Rodda, T. H. Fritts, and R. L. Bruggers. 1999. An integrated management plan for the Brown Treesnake (Boiga irregularis) on Pacific islands. Pages 423-435 in G. H. Rodda, Y. Sawai, D. Chiszar, and H. Tanaka, eds. Problem snake management: The Habu and the Brown Treesnake. Cornell University Press, Ithaca, New York.

Capocaccia, L. 1977. Contribution to the study of the snakes of Java (Indonesia) [in Italian with English summary]. Ann. Mus. Civ. Stor. Nat. "Giacomo Doria" 81:5195.

Caudell, J. N. 2001. Pathophysiology and predation of Brown Tree Snakes in Australia. Ph.D. diss., Jack H. Berryman Institute for Wildlife Damage Management, Utah State University, Logan.

Caudell, J. N., J. M. Whittier, and M. R. Conover. 2002. The effects of haemogregarine-like parasites on Brown Tree Snakes (Boiga irregularis) and Slateygrey Snakes (Stegonotus cucullatus) in Queensland, Australia. Int. Biodeterior. Biodegrad. 49:113-119.

Chiszar, D. 1990. The behavior of the Brown Tree Snake, Boiga irregularis: A study in applied comparative psychology. Pages 101-123 in D. A. Dewsbury, ed. Contemporary issues in comparative psychology. Sinauer Assoc., Sunderland, Massachusetts.

- 1992. Chemical control of predatory behavior in the Brown Tree Snake (Boiga irregularis). Snake 24:108.

- 1999. Behavioral and sensory biology highlights: Differences between laboratory and field tests. Pages 490-492 in G. H. Rodda, Y. Sawai, D. Chiszar, and H. Tanaka, eds. Problem snake management: The Habu and the Brown Treesnake. Cornell University Press, Ithaca, New York.

Chiszar, D., D. Carrillo, P. Rand, J. W. Chiszar, and H. M. Smith. 1985. Nocturnal activity in captive Brown Tree Snakes, Boiga irregularis. Bull. Md. Herpetol. Soc. 21:115-118. 
Chiszar, D., T. M. Dunn, and H. M. Smith. 1999. Predatory behavior of Brown Treesnakes (Boiga irregularis): Laboratory studies of chemical attractants. Pages 187195 in G. H. Rodda, Y. Sawai, D. Chiszar, and H. Tanaka, eds. Problem snake management: The Habu and the Brown Treesnake. Cornell University Press, Ithaca, New York.

Chiszar, D., and K. Kandler. 1986. Adjustment of Brown Tree Snakes (Boiga irregularis) to a reversed light cycle. Bull. Md. Herpetol. Soc. 22:171-174.

Chiszar, D., K. Kandler, R. Lee, and H. M. Smith. 1988a. Stimulus control of predatory attack in the Brown Tree Snake (Boiga irregularis). 2. Use of chemical cues during foraging. Amphib.-Reptilia 9:77-88.

Chiszar, D., K. Kandler, and H. M. Smith. 1988b. Stimulus control of predatory attack in the Brown Tree Snake (Boiga irregularis) 1 . Effects of visual cues arising from prey. Snake 20:151-155.

Chiszar, D., G. H. Rodda, and H. M. Smith. 1997. Experiments on chemical control of behavior in Brown Tree Snakes. Pages 121-127 in J. R. Mason, ed. Repellents in wildlife management. U.S. Department of Agriculture National Wildlife Research Center, Fort Collins, Colorado.

Colvin, B. A., M. W. Fall, L. A. Fitzgerald, and L. L. Loope. 2005. Review of Brown Treesnake problems and control programs: Report of observations and recommendations. Report to Office of Insular Affairs, Honolulu, Hawai'i.

Covacevich, J., and C. J. Limpus. 1973. Two large winter aggregations of three species of tree-climbing snakes in south-eastern Queensland. Herpetofauna 6:16-21.

Dobson, A. P. 1988. Restoring island ecosystems: The potential of parasites to control introduced mammals. Conserv. Biol. 2:3139.

Ehmann, H. 1992. Encyclopedia of Australian animals: Reptiles. Angus and Robertson, Pymble, New South Wales, Australia. 1993. Family Colubridae. Pages 290-294 in C. J. Glasby, G. J. B. Ross, and P. L. Beeseley, eds. Fauna of Australia.
Vol 2A. Amphibia and Reptilia. Australian Government Publishing Service, Canberra.

Engeman, R. M., and M. A. Linnell. 1998. Trapping strategies for deterring the spread of Brown Tree Snakes from Guam. Pac. Conserv. Biol. 4:348-353.

Engeman, R. M., M. A. Linnell, D. S. Vice, and M. E. Pitzler. 1998. Efficacy of the methods used in an integrated program to deter the spread of Brown Tree Snakes from Guam. Proc. Aust. Vertebr. Pest Conf. 11:435-440.

Engeman, R. M., D. S. Vice, D. L. York, and K. S. Gruver. 2002. Sustained evaluation of the effectiveness of detector dogs for locating Brown Tree Snakes in cargo outbound from Guam. Int. Biodeterior. Biodegrad. 49:101-106.

Fritts, T. H. 1988. The Brown Tree Snake, Boiga irregularis, a threat to Pacific islands. U.S. Fish Wildl. Serv., Biol. Rep. 88 (31).

. 1994. Does the Brown Tree Snake pose a threat to Florida and its tourist industry? Pages 71-73 in D. C. Schmitz and T. C. Brown, eds. An assessment of invasive non-indigenous species in Florida's public lands. Fla. Dep. Environ. Prot., Tech. Rep. TSS-94-100.

. 2002. Economic costs of electrical system instability and power outages caused by snakes on the island of Guam. Int. Biodeterior. Biodegrad. 49:93-100.

Fritts, T. H., and D. Chiszar. 1999. Snakes on electrical transmission lines: Patterns, causes, and strategies for reducing electrical outages due to snakes. Pages 89-103 in G. H. Rodda, Y. Sawai, D. Chiszar, and H. Tanaka, eds. Problem snake management: The Habu and the Brown Treesnake. Cornell University Press, Ithaca, New York.

Fritts, T. H., and M. J. McCoid. 1991. Predation by the Brown Tree Snake on poultry and other domesticated animals in Guam. Snake 23:75-80.

. 1999. The threat to humans from snakebite by snakes of the genus Boiga based on data from Guam and other areas. Pages 116-127 in G. H. Rodda, Y. Sawai, 
D. Chiszar, and H. Tanaka, eds. Problem snake management: The Habu and the Brown Treesnake. Cornell University Press, Ithaca, New York.

Fritts, T. H., M. J. McCoid, and D. M. Gomez. 1999. Dispersal of snakes to extralimital islands: Incidents of the Brown Treesnake, Boiga irregularis, dispersing to islands in ships and aircraft. Pages 209223 in G. H. Rodda, Y. Sawai, D. Chiszar, and H. Tanaka, eds. Problem snake management: The Habu and the Brown Treesnake. Cornell University Press, Ithaca, New York.

Fritts, T. H., M. J. McCoid, and R. L. Haddock. 1990. Risks to infants on Guam from bites of the Brown Tree Snake (Boiga irregularis). Am. J. Trop. Med. Hyg. 42:607-611.

. 1994. Symptoms and circumstances associated with bites by the Brown Tree Snake (Colubridae: Boiga irregularis) on Guam. J. Herpetol. 28:27-33.

Fritts, T. H., and G. H. Rodda. 1998. The role of introduced species in the degradation of island ecosystems: A case history of Guam. Annu. Rev. Ecol. Syst. 29:113140.

Fritts, T. H., N. J. Scott Jr., and J. A. Savidge. 1987. Activity of the arboreal Brown Tree Snake (Boiga irregularis) on Guam as determined by electrical power outages. Snake 19:51-58.

Gee, D. E., II. 2002. Appraisal of visual stimuli in the contexts of directional movement and courtship in the Brown Tree Snake (Boiga irregularis). Independent Study Thesis, College of Wooster, Wooster, Ohio.

Gow, G. F. 1976. Snakes of Australia. Angus and Robertson, London.

Greene, H. W. 1989. Ecological, evolutionary, and conservation implications of feeding biology in Old World cat snakes, genus Boiga (Colubridae). Proc. Calif. Acad. Sci., Ser. 4 46:193-207.

Greene, M. J. 1999. Pheromonal mediation of reproductive behavior in the Brown Tree Snake. Ph.D. diss., Oregon State University, Corvallis.
Greene, M. J., and R. T. Mason. 1998. Chemically mediated sexual behavior of the Brown Tree Snake, Boiga irregularis. Ecoscience 5:405-409.

- 2000. Courtship, mating, and male combat of the Brown Tree Snake, Boiga irregularis. Herpetologica 56:166-175.

. 2003. Pheromonal inhibition of male courtship behaviour in the Brown Tree Snake, Boiga irregularis: A mechanism for the rejection of potential mates. Anim. Behav. 65:905-910.

- 2005. The effects of cloacal secretions on Brown Tree Snake behavior. Pages 49-55 in R. T. Mason, M. P. LeMaster, and D. Müller-Schwarze, eds. Chemical signals in vertebrates, $X$. Kluwer Academic/Plenum Publishers, New York.

Greene, M. J., S. L. Stark, and R. T. Mason. 2001. Pheromone trailing behavior of the Brown Tree Snake, Boiga irregularis. J. Chem. Ecol. 27:2193-2201.

- 2002. The predatory response of the Brown Tree Snake to human skin odor. J. Chem. Ecol. 28:2459-2467.

Greer, A. E. 1997. The biology and evolution of Australian snakes. Surrey Beatty \& Sons, Chipping Norton, New South Wales, Australia.

Guam Department of Commerce. 1998. Economic indicator series: General. Guam Econ. Rev. Q. Rep. 20 (2): 12-27.

Guyer, C., and M. A. Donnelly. 1990. Length-mass relationships among an assemblage of tropical snakes in Costa Rica. J. Trop. Ecol. 6:65-76.

Hayes, W. K., P. A. Lavín-Murcio, and K. V. Kardong. 1992. Recent studies on venom expenditure of viperid and colubrid snakes. Abstract. Page 57 in Proceedings, Society for the Study of Amphibians and Reptiles, 35th Annual Meeting, El Paso, Texas.

- 1993. Delivery of Duvernoy's secretion into prey by the Brown Tree Snake, Boiga irregularis (Serpentes: Colubridae). Toxicon 31:881-887.

Holzman, D. 1999. Viruses considered for controlling bird-eating snakes on Guam. Am. Soc. Microbiol. Newsl. 65 (3): 1-3.

Hoser, R. T. 1980. Further records of aggre- 
gations of various species of Australian snakes. Herpetofauna 12:16-22.

1999. Sydney's snakes. Privately published, www.smuggled.com/sydney.htm.

Jackson, K., and T. H. Fritts. 1995. Evidence from tooth surface morphology for a posterior maxillary origin of the proteroglyph fang. Amphib.-Reptilia 16:273-288.

Jakes, K. A., P. O'Donoghue, and J. M. Whittier. 2003. Ultrastructure of Hepatozoon boigae (Mackerras, 1961) nov. comb. from Brown Tree Snakes, Boiga irregularis, from northern Australia. Parasitol. Res. 34:225-231.

Johnston, J. J., P. J. Savarie, T. M. Primus, J. D. Eisemann, J. C. Hurley, and D. J. Kohler. 2002. Risk assessment of an acetaminophen baiting program for chemical control of Brown Tree Snakes on Guam: Evaluation of baits, snake residues, and potential primary and secondary hazards. Environ. Sci. Technol. 36:3827-3833.

Kinghorn, J. R. 1964. The snakes of Australia. 3rd ed. Angus and Robertson, Sydney.

Mackessy, S. P., N. M. Sixberry, W. H. Heyborne, and T. H. Fritts. 2006. Venom of the Brown Treesnake, Boiga irregularis: Ontogenetic shifts and taxa-specific toxicity. Toxicon 45:537-548.

Mason, R. T., and M. J. Greene. 2001. Invading pest species and the threat to biodiversity: Pheromonal control of Guam Brown Tree Snakes, Boiga irregularis. Pages 361368 in A. Marchlewski-Koj, J. Lepri, and D. Müller-Schwarze, eds. Chemical signals in vertebrates, IX. Kluwer Academic/ Plenum Publishers, New York.

Mathies, T., T. A. Felix, and V. A. Lance. 2001. Effects of trapping and subsequent short-term confinement stress on plasma corticosterone in the Brown Treesnake (Boiga irregularis) on Guam. Gen. Comp. Endocrinol. 124:106-114.

Mathies, T., E. A. Franklin, and L. A. Miller. 2004. Proximate cues for ovarian recrudescence and ovulation in the Brown Treesnake (Boiga irregularis) under laboratory conditions. Herpetol. Rev. 35:46-49.

Mathies, T., and L. A. Miller. 2003. Cool temperatures elicit reproduction in the biologically invasive predator, the Brown
Treesnake (Boiga irregularis). Zoo Biol. 22:227-238.

McCoid, M. J. 1994. Boiga irregularis (Brown Tree Snake) reproduction. Herpetol. Rev. 25:69-70.

Moore, I. T., M. J. Greene, D. T. Lerner, C. E. Asher, R. W. Krohmer, D. L. Hess, J. M. Whittier, and R. T. Mason. 2005. Physiological evidence for reproductive suppression in the introduced population of Brown Tree Snakes (Boiga irregularis) on Guam. Biol. Conserv. 121:91-98.

Morton, S. R., and C. D. James. 1988. The diversity and abundance of lizards in arid Australia: A new hypothesis. Am. Nat. 132:237-256.

Murata, Y., H. J. C. Yeh, L. K. Pannell, T. H. Jones, H. M. Fales, and R. T. Mason. 1991. New ketodienes from the integumental lipids of the Guam Brown Tree Snake Boiga irregularis. J. Nat. Prod. (Lloydia) 54:233-240.

National Wildlife Research Center. 2003. Innovative solutions to human-wildlife conflicts: National Wildlife Research Center accomplishments 2002. U.S. Dep. Agric. Anim. Plant Health Inspect. Serv. Misc. Publ. 1587.

Parker, W. S., and M. V. Plummer. 1987. Population ecology. Pages 253-301 in R. A. Siegel, J. T. Collins, and S. S. Novak, eds. Snakes: Ecology and evolutionary biology. Macmillan, New York.

Perry, G., E. W. Campbell III, G. H. Rodda, and T. H. Fritts. 1998. Managing island biotas: Brown Treesnake control using barrier technology. Pages 138-143 in R. O. Baker and A. C. Crabb, eds. Proceedings, 18th Vertebrate Pest Conference, University of California, Davis.

Rawlings, L. H. 1995. Phylogeography of the Brown Tree Snake, Boiga irregularis, particularly relating to populations in Guam. B.S. (Honours) thesis, University of Adelaide, Adelaide, South Australia.

Rodda, G. H., and K. Dean-Bradley. 2002. Excess density compensation of island herpetofaunal assemblages. J. Biogeogr. 29:110.

Rodda, G. H., and T. H. Fritts. 1992a. The impact of the introduction of the Brown 
Tree Snake, Boiga irregularis, on Guam's lizards. J. Herpetol. 26:166-174.

. 1992b. Sampling techniques for an arboreal snake, Boiga irregularis. Micronesica 25:23-40.

Rodda, G. H., T. H. Fritts, and E. W. Campbell III. 1999a. The feasibility of controlling the Brown Treesnake in small plots. Pages 468-477 in G. H. Rodda, Y. Sawai, D. Chiszar, and H. Tanaka, eds. Problem snake management: The Habu and the Brown Treesnake. Cornell University Press, Ithaca, New York.

Rodda, G. H., T. H. Fritts, E. W. Campbell III, K. Dean-Bradley, G. Perry, and C. P. Qualls. 2002. Practical concerns in the eradication of island snakes. Pages 260265 in C. R. Veitch and M. N. Clout, eds. Turning the tide: The eradication of invasive species. IUCN Invasive Species Specialist Group of the World Conservation Union (IUCN), Gland, Switzerland.

Rodda, G. H., T. H. Fritts, and D. Chiszar. 1997. The disappearance of Guam's wildlife: New insights for herpetology, evolutionary ecology, and conservation. BioScience 47:565-574.

Rodda, G. H., T. H. Fritts, and P. J. Conry. 1992. Origin and population growth of the Brown Tree Snake, Boiga irregularis, on Guam. Pac. Sci. 46:46-57.

Rodda, G. H., T. H. Fritts, M. J. McCoid, and E. W. Campbell III. 1999b. An overview of the biology of the Brown Treesnake, Boiga irregularis, a costly introduced pest on Pacific Islands. Pages 44-80 in G. H. Rodda, Y. Sawai, D. Chiszar, and H. Tanaka, eds. Problem snake management: The Habu and the Brown Treesnake. Cornell University Press, Ithaca, New York.

Rodda, G. H., T. H. Fritts, G. Perry, and E. W. Campbell III. 1998. Managing island biotas: Can indigenous species be protected from introduced predators such as the Brown Treesnake? Pages 95-108 in K. G. Wadsworth, ed. Trans. 63rd North Am. Wildl. Nat. Resour. Conf. Wildl. Manage. Inst., Washington, D.C.

Rodda, G. H., M. J. McCoid, T. H. Fritts, and E. W. Campbell III. 1999c. Population trends and limiting factors in Boiga irregularis. Pages 236-253 in G. H. Rodda, Y. Sawai, D. Chiszar, and H. Tanaka, eds. Problem snake management: The Habu and the Brown Treesnake. Cornell University Press, Ithaca, New York.

Rodda, G. H., J. A. Savidge, C. L. Tyrrell, M. T. Christy, and A. R. Ellingson. 2007. Size bias in visual searching and trapping of Brown Treesnakes on Guam. J. Wildl. Manage. 71: (in press).

Savarie, P. J., and R. L. Bruggers. 1999. Candidate repellents, oral and dermal toxicants, and fumigants for Brown Treesnake control. Pages 417-422 in G. H. Rodda, Y. Sawai, D. Chiszar, and H. Tanaka, eds. Problem snake management: The Habu and the Brown Treesnake. Cornell University Press, Ithaca, New York.

Savarie, P. J., J. A. Shivik, G. C. White, J. C. Hurley, and L. Clark. 2001. Use of acetaminophen for large scale control of Brown Treesnakes. J. Wildl. Manage. 65:356365.

Savidge, J. A. 1986. The role of disease and predation in the decline of Guam's avifauna. Ph.D. diss., University of Illinois, Urbana-Champaign.

- 1987a. The ecological and economic impacts of an introduced snake on Guam and its threat to other Pacific islands. Ples 3:29-34.

- 1987b. Extinction of an island forest avifauna by an introduced snake. Ecology 68:660-668.

. 1988. Food habits of Boiga irregularis, an introduced predator on Guam. J. Herpetol. 22:275-282.

- 1991. Population characteristics of the introduced Brown Tree Snake (Boiga irregularis) on Guam. Biotropica 23:294300.

Savidge, J. A., F. J. Qualls, and G. H. Rodda. 2007. Reproductive biology of the Brown Tree Snake, Boiga irregularis (Reptilia: Colubridae), during colonization of Guam and comparison with that of their native range. Pac. Sci. 61:187-195.

Schwenk, K. 1995. Of tongues and noses: Chemoreception in lizards and snakes. Trends Ecol. Evol. 10:7-12. 
Shine, R. 1991. Strangers in a strange land: Ecology of Australian colubrid snakes. Copeia 1991:120-131.

Storr, G. M., L. A. Smith, and R. E. Johnstone. 1986. Snakes of Western Australia. Western Australia Museum, Perth.

Telford, S. R., Jr. 1999. The possible use of haemogregarine parasites in biological control of the Brown Treesnake (Boiga ir regularis) and the Habu (Trimeresurus flavoviridis). Pages 384-390 in G. H. Rodda, Y. Sawai, D. Chiszar, and H. Tanaka, eds. Problem snake management: The Habu and the Brown Treesnake. Cornell University Press, Ithaca, New York.

U.S. Fish and Wildlife Service. 2005. Draft revised recovery plan for the Aga or Mariana Crow, Corvus kubaryi. U.S. Fish and Wildlife Service, Region 1, Portland, Oregon.

Vest, D. K., S. P. Mackessy, and K. V. Kardong. 1991. The unique Duvernoy's secretion of the Brown Tree Snake (Boiga irregularis). Toxicon 29:532-535.

Vice, D. S., and R. M. Engeman. 2000. Brown Tree Snake discoveries during detector dog inspections following Supertyphoon Paka. Micronesica 33:105-110.

Vice, D. S., R. M. Engeman, and D. L. Vice. 2005. A comparison of three trap designs for capturing Brown Treesnakes on Guam. Wildl. Res. 32:355-359.

Vice, D. S., and M. E. Pitzler. 2002. Brown Treesnake control: Economy of scales. Pages 127-131 in L. Clark, J. Hone, J. A. Shivik, R. A. Watkins, K. C. Vercauteren, and J. K. Yoder, eds. Human conflicts with wildlife: Economic considerations. Proceedings, 3rd Special Symposium, National Wildlife Research Center, Fort Collins, Colorado.

Vice, D. S., and D. L. Vice. 2004. Characteristics of Brown Treesnakes removed from Guam's transportation network. Pac. Conserv. Biol. 10:216-221.

Weinstein, S. A., D. Chiszar, R. C. Bell, and L. A. Smith. 1991. Lethal potency and fractionation of Duvernoy's secretion from the Brown Tree Snake, Boiga irregularis. Toxicon 29:401-407.

Weinstein, S. A., B. G. Stiles, M. J. McCoid, L. A. Smith, and K. V. Kardong. 1993. Variation of lethal potencies and acetylcholine receptor binding activity of Duvernoy's secretions from the Brown Tree Snake Boiga irregularis. Merrem. J. Nat. Toxins 2:187-198.

Weldon, P. J., B. J. Demeter, T. S. Walsh, and J. S. E. Kleister. 1994. Chemoreception in the feeding behavior of reptiles: Considerations for maintenance and management. Pages 61-70 in J. B. Murphy, K. Adler, and J. T. Collins, eds. Captive management and conservation of amphibians and reptiles. Soc. Study Amphib. Reptiles, Contrib. Herpetol. 11.

Whittier, J. M., and D. Limpus. 1996. Reproductive patterns of a biologically invasive species: The Brown Tree Snake (Boiga irregularis) in eastern Australia. J. Zool. (Lond.) 238:591-597.

Whittier, J. M., C. Macrokanis, and R. T. Mason. 2000. Morphology of the Brown Tree Snake, Boiga irregularis, with a comparison of native and extralimital populations. Aust. J. Zool. 48:357-367.

Whittier, J. M., and P. O'Donoghue. 1998. A survey of the parasites and diseases of the Brown Tree Snake in its native range. Final report to Hawai'i Department of Agriculture, Honolulu.

Wiles, G. J. 1987. Current research and future management of Marianas fruit bats (Chiroptera: Pteropodidae) on Guam. Aust. Mammal. 10:93-95.

1989. Natural history, biology, and habitat protection for the Marianas fruit bats. Pages 59-71 in C. F. Aguon, G. J. Wiles, and L. L. Mariano, eds. Annual report, fiscal year 1989. Guam Division of Aquatic Wildlife Resources, Mangilao.

Zwinenberg, A. J. 1978. Die Braune Nachtbaumnatter Boiga irregularis. Aquarien Terrarien Z. 31:177-179. 